tection in passenger and cargo ships, another with the safety precautions against accidents operating in the several factories belonging to the Group.

\section{Forest Diseases and Insects}

A GREAT deal of effort and investment is being directed to increasing forest production, but there are certain factors which are reducing the desired results. Many of these factors were discussed at a symposium held under the aegis of the Food and Agriculture Organization and the International Union of Forest Research Organizations at Oxford during July 1964 on "Internationally Dangerous Forest Diseases and Insects" (Unasylva, 19 (3), No. 78; 1965. Food and Agriculture Organization. 3s. 3d.). Very little factual information is available on losses due to these causes, but in the United States it was estimated in 1952 that they accounted for 35 per cent of the gross annual growth. Although old natural forest stands suffer most from decay and insect-caused mortality, the main concern of the future may be in the man-made forests, many of which are characterized by exotic species in pure, even-aged stands. Thus new problems are possibly being created. Of the various control measures likely to be practical on a forest scale, it seems that the so-called 'natural' ones hold certain advantages. Appropriate silviculture and forest management can manipulate the species, stand composition and rotation and so help prevent disease and insect damage. This really involves no extra cost and the same may be said of biological control measures which can be self-perpetuating. On the other hand, although chemical control has the advantages of being rapid, easily applied and available for use against many insects and fungi, its economics are complex and its possible side-effects tend to strike a warning note. Very sound recommendations were passed at the symposium and these included the need for more pathologists and entomologists, for more research and the quantitative evaluation of losses, for the certification of seed, the quarantine of plants and their disinfection and disinfestation and for annual reports from all countries on disease and insect conditions. This volume of Unasylva is a very fine synopsis of the main subjects discussed at the symposium. It is to be followed by the publication in two volumes of the individual papers and by a third volume on Diseases of Widely Planted Forest Trees. These will make available a great deal of useful information on subjects that are becoming more and more important in forestry practice.

\section{Vegetation Types}

MAPs of vegetation types can be of great value to the silviculturist and forest manager because they indicate site conditions, and site is a very important factor influencing production. The need for more detailed maps of vegetation types for parts of the Swiss Jura lying to the north-west of Lake Neuchâtel came about as a result of old silver fir stands suffering from the drought years of 1945-50. These stands, with southerly aspects and situated on shallow, calcareous soils, began to perish when, in their weakened state, they suffered from bark beetle attack (Ips curvidens). Thus, the Forest Service was faced with reforestation work, and so it was decided to make a detailed investigation of the natural vegetation of the region. This was done during the 10-year period ending in 1961 and the results are now available (Extraits de la Carte Phytosociologique des Forêts du Canton de Neuchâtel. Par Jean-Louis Richard. Commission Phytogéographique de la Société Helvétique des Sciences Naturelles. Matériaux pour le levé Géobotanique de la Suisse, Fascicule 47. Pp. $48+1$ carte. Berne: Editions Hans Huber, 1965. 25 Sw. francs). It is claimed that in most of the forests of the Swiss Jura, man has nowhere degraded the natural vegetation to such an extent that it is irreversible. Indeed, even some changes in the woody vegetation have scarcely affected the herbaceous cover and the soil, and so there is little difference between the actual and the potential vegetation. Thus, where potential and not actual vegetation has been mapped, this has been done without fear of any risk of serious error. Four blocks of forest totalling more than 26,000 hectares were examined and their physical features, geology, soils and vegetation are described. Twenty-eight natural forest associations are listed, together with their characteristic species and notes on the soils. The vegetation type map with three blocks on a scale of $1: 25,000$ and one at $1: 10,000$ shows a wealth of detail and the reproduction is excellent. It is true to say that the entire work and its usefulness are typical of the efficiency that is associated with Swiss forestry.

\section{Physiodormancy}

Dr. John Wiebe, of the Horticultural Experiment Stations, Vineland Station, Ontario, has written to the Editor as follows: "All deciduous, temperate zone, perennial plants cease growth and enter dormancy at some time in summer or autumn. They remain dormant until growth begins again in spring under favourable moisture and temperature conditions. Frequently, temperature and moisture conditions in late summer and autumn are favourable for the continuation of growth, yet the plant remains dormant. If a dormant plant is brought into a greenhouse before its rest period, or cold period requirement, has been satisfied, it will remain dormant. Once the rest period has been satisfied by exposure to a suitably low temperature for a sufficient time, the plant is capable of resuming growth as soon as it is in a favourable environment. Because of continuing unfavourable temperature, it may however, and usually does, remain dormant for some time after its rest period has been satisfied. Because 'rest period' or 'cold period requirement' are ambiguous terms, I propose the term 'physiodormancy' for that component of the dormaney of a plant which is controlled by physiological or biochemical agents. Thus, a plant is said to be physiodormant when it will not start into growth at normally favourable conditions of moisture and temperature. The plant may continue to remain dormant, when it is no longer physiodormant, if temperature or lack of moisture prevents the resumption of growth".

\section{Scientific Research}

Scientific Research is a new addition to the list of monthly magazines which may be received gratis by those actively engaged in research in physics, chemistry or the life sciences. J. D. Luntz, editor and publisher of the magazine for McGraw.Hill, Inc., states in the first issue (January 1966) that the contents provide interpretative commentary on technical developments, selected technical articles, and new product information of specific use to experimenters. The feature article in the first issue is by C. Laverick on superconducting magnets, and the new products section consists of comprehensive surveys of commercially available (English, American and Japanese) storage oscilloscopes and American signalaveraging computers, together with a preview of some of the instruments which were exhibited at the Physics Show in New York during the annual meeting of the American Physical Society and American Association of Physics Teachers during January 26-29, 1966. A literature survey and reader service card are included. Three new improved designs of electron-microscopes, computer timesharing, and a report on the disastrous fire that wrecked the Cambridge (Massachusetts) electron accelerator bubble chamber hall in July 1965, form the main features of "Science Roundup", the section dealing with recent developments. 